\title{
KAJIAN TERHADAP METODOLOGI TAFSIR AL-AMANAH
}

\author{
Ruslan \\ Fakultas Ushuluddin dan Dakwah IAIN Bone \\ ruslanssangaji@gmail.com
}

\begin{abstract}
This article aims to describe the methodology of the interpretation of AlAmanah by Quraish Shihab. The method of presentation is descriptive qualitative, in the sense that the data presented is as is. Tafsir al-amanah is the forerunner to the compilation of al-Qur'an al-Karim Tafsir: Interpretation of Short Letters Based on the Revelation of Revelation. Which is the work of commentary Quraish Shihab, published in 1997 by Pustaka Hidayah in Bandung. Initially the writings that were published in the magazine Amanah. This interpretation only contains two discourse of the letter, namely surah al'Alaq and al-Mudatstsir. The writing style is still very simple. Tafsir alAmanah is classified as a description of tahliliy because of its coherent description from verse to verse. In addition, this interpretation can also be called its presentation as a thematic interpretation dish, but this interpretation is not very popular compared to the work of other Quraish Shihab interpretations which are not thematic as constructed by Al-Farmawi. AlAmanah's interpretation methodology can inspire especially those who are interested in interpreting other interpretations. In terms of methodology, Tafsir Al Amanah includes the interpretation of bi al-riwayah and bi aldirayah. The combination of the two streams or colors of interpretation which has been known. Tafsir Al-Amanah has a detailed, detailed, in-depth and comprehensive interpretation. Key terms in each verse are analyzed by multianalysis and the study of asbab al-nuzul is not spared as part of its interpretation method as long as the verse has asbab al-nuzul. linguistic and sociohistorical analysis.
\end{abstract}

Keywords: Interpretation, methodology, al-amanah, and analysis.

\begin{abstract}
Abstrak
Artikel ini bertujuan mendeskripsikan metodologi tafsir Al-Amanah karya Quraish Shihab. Metode penyajiannya adalah deskriptif kualitatif, dalam artian bahwa data yang disajikan apa adanya. Tafsir al-amanah merupakan cikal bakal tersusunnya Tafsir al-Qur'an al-Karim: Tafsir atas Surat-surat Pendek Berdasarkan Urutan Turunnya Wahyu. Yang merupakan karya tafsir Quraish Shihab yang terbit pada tahun 1997 oleh Pustaka Hidayah di Bandung. Awalnya merupakan tulisan-tulisan yang pernah dimuat di majalah Amanah. Tafsir ini hanya memuat dua bahasan surat, yaitu surat al-'Alaq dan al-Mudatstsir. Gaya penulisannya masih sangat sederhana. Tafsir al-Amanah digolongkan sebagai
\end{abstract}


uraian tahliliy karena runtut uraiannya dari ayat ke ayat. Di samping itu, tafsir ini juga bisa disebut penyajiannya sebagai sajian tafsir tematik, namun tafsir ini tidak terlalu popular dibandingkan dengan karya tafsir Quraish Shihab lainnya bukan tematik yang seperti dikonstruksi oleh Al-Farmawi. Metodologi tafsir AlAmanah dapat menginspirasi khususnya bagi peminat tafsir dalam menyusun karya-karya tafsir lain. Segi metodologis, Tafsir Al Amanah termasuk tafsir $b i$ al-riwayah dan bi al-dirayah. Gabungan dari kedua aliran atau warna tafsir yang selama ini dikenal. Tafsir Al-Amanah memiliki sajian tafsir yang rinci, mendetail, mendalam, dan komprehensif. Terma-terma kunci di setiap ayat dianalisis dengan multi analisisis serta kajian asbab al-nuzul tidak luput diangkat sebagai bagian dari metode penafsirannya selama ayat itu memiliki asbab alnuzul. analisis linguistik serta sosiohistoris.

Kata kunci: Tafsir, metodologi, al-amanah, dan analisis.

\section{PENDAHULUAN}

Alquran, dalam tradisi pemikiran Islam telah melahirkan sederetan teks turunan yang demikian luas dan mengagumkan. Teks-teks turunan itu merupakan teks kedua bila Alquran dipandang sebagai teks pertama yang menjadi pengungkap dan penjelas makna-makna yang terkandung di dalamnya. Teks kedua ini lalu dikenal sebagai literatur tafsir Alquran, ditulis oleh para ulama dengan kecenderungan dan karakteristik masing-masing.

Dibandingkan dengan kitab suci agama lain, tentu ini merupakan suatu fenomena yang unik. Sebab, kitab-kitab tafsir sebagai teks kedua itu, tidak sekedar jumlahnya yang banyak, tetapi juga corak dan model metode yang dipakai beragam dan berbeda-beda.

Keragaman karya tafsir, tentu tidak lepas dari penentuan metode dan pendekatan yang digunakan. Lihatlah misalnya sejumlah tafsir yang muncul sebelumnya seperti, tafsir al-Durr al-Mantsur fi al-Tafsir al-Ma'tsur karya Jalaluddin al-Suyuthi (849-911 H.), Jami al-Bayan fi Tafsir al-Qur'an karya Abu Ja'far Muhammad bin Jarir alThabary (224-310 H.), dan Tafsir al-Qur'an al- 'Adzim karya 'Imaduddin Abu al-Fida al-Quraisyi al-Dimasyqi bin Katsir (700-774 H.)

Tradisi penulisan karya tafsir di Indonesia juga telah berkembang cukup lama, dengan keragaman teknis penulisan, corak dan bahasa yang dipakai. Dinamika penulisannya cukup dirasakan dari masa ke masa. Bahkan telah banyak dilakukan penelitian terhadap karya tafsir yang lahir dibumi nusantara ini, salah satunya yang pernah diterobos oleh Howard M. Federspiel terhadap 60 literatur karya yang konsern pada Alquran dan tafsirnya. Ini membuktikan juga kalau di Indonesia secara historis 
pengkajian terhadap Alquran yang melahirkan buah karya tafsir, mengalami perkembangan yang signifikan. ${ }^{1}$

Artikel ini tersendiri akan menyoroti salah satu buah karya dari Quraish Shihab, yaitu Tafsir Al Amanah. Tafsir ini awalnya pernah dipublikasikan melalui majalah amanah kemudian dibukukan. Penulis mencoba membedah kitab ini dengan menitikberatkan pada kajian tentang metodologinya.

Aspek metodologi dari sebuah karya tafsir layak memang dicermati. Oleh karena prinsip metodologi yang digunakan dalam memahami teks Alquran, sangat beragam, apalagi yang menjadi objek kajian adalah literatur berbahasa Indonesia. Adakah kemiripan metodologis dengan yang ada di Timur Tengah? Atau apakah hal-hal yang bersifat teknik penulisan yang ada dalam tafsir Al Amanah merupakan duplikat dari gaya penulisan mufassir sebelumnya?. Berdasrkan uraian sebelumnya, perlu kiranya mengangkat rumusan masalah yang akan menjadi patokan uraian selanjutnya yaitu, bagaimanakah gambaran Tafsir Al Amanah?, dan bagaimanakah metodologi Tafsir Al Amanah?

\section{METODE PENELITAN}

Arikel ini ditulis dengan menggunakan metode pustaka (library research). selanjutnya disajikan dengan cara deskriptif kualitatif. Penyajiannya dilakukan sebagaimana biasanya dilakukan pada penelitian atau kajan atas buku tertentu. Segala bentuk karakteristik dalam penyajian tafsir Al-Amanah dideskripsikan apa adanya sehingga menggambarkan spesifikasi metodologinya secara utuh. Di samping itu, juga menggunakan analisis isi (content analysis).

\section{HASIL DAN PEMBAHASAN \\ Biografi Pengarang}

Quraish Shihab lahir di Rappang, Sulawesi Selatan, pada 16 Pebruari 1944. Pendidikan dasarnya diselesaikan di Makassar kemudian melanjutkan pendidikan menengahnya di Malang sambil belajar di Pondok Pesantren Darul Hadis al-Faqihiyyah. Dilihat dari segi silsilah keluarganya, mereka umumnya tergolong orang-orang berpendidikan. Ayahnya, Abdurrahman Syihab (1905-1986) adalah alumni Jami'atul Khair Jakarta yang merupakan lembaga pendidikan Islam tertua di Indonesia. Bahkan, disamping pernah menjabat Rektor IAIN Alauddin (sekarang UIN Makassar), ia juga termasuk guru besar dalam bidang Tafsir. Jadi, bisa dikatakan, secara tidak langsung Quraish Shihab mendapatkan banyak pengajaran yang berkaitan dengan Alquran dari ayahnya sejak masih kecil.

\footnotetext{
${ }^{1}$ Howard M. Federsipel, Kajian Alquran Di Indonesia: Dari Mahmud Yunus hingga Quraish Shihab (Bandung: Mizan, 1996), h. 27
} 
Jelas sekali uraian Quraish Shihab dalam “mukaddimah” buku Membumikan Alquran, ia mengatakan bahwa ayahnya seringkali mengajaknya duduk bersama untuk mendapatkan petuah-petuah keagamaan. Banyak dari petuah itu yang kemudian baru diketahui kalau ternyata juga bersumber dari Alquran, petuah Nabi, sahabat, atau pakarpakar Alquran. Menurutnya, petuah itu masih terngiang ditelinganya. Misalnya:

"Aku akan palingkan (tidak memberikan) ayat-ayat-Ku kepada mereka yang bersikap angkuh di permukaan bumi .... (QS. Al-A'raf(7): 146 “

"Alquran adalah jamuan Tuhan"

"Biarkanlah Alquran berbicara (Istantiq Alqur'an), "Sabda 'Ali bin Abi Thalib.

"Bacalalah Alquran seakan-akan ia diturunkan kepadamu," kata Muhammad Iqbal"

"Rasakan keagungan Alquran, sebelum kau menyentuhnya dengan nalarmu," kata Syaikh Muhammad Abduh. ${ }^{2}$

Petuah-petuah seperti ini sangat memotivasi dirinya hingga benih kecintaan kepada studi Alquran mulai tersemai dalam jiwanya

Pada 1958, Quraish hijrah ke Kairo, Mesir untuk melanjutkan pendidikannya. Ia diterima di kelas II Tsanawiyah al-Azhar. Di kota yang sama, ia juga melanjutkan pendidikan S-1 nya pada Fakultas Ushuluddin Jurusan Tafsir dan Hadis Universitas AlAzhar hingga meraih gelar Lc pada tahun 1967. Selanjutnya, pada tahun 1969 gelar MA pun diraihnya untuk spesialisasi bidang Tafsir Alquran. Judul tesisnya adalah Al-I'jaz Al-Tasyri'iy li Al-Qur'an al-Karim.

Setelah kembali ke Makassar, beberapa jabatan diberikan padanya, antara lain: Wakil Rektor bidang Akademik dan Kemahasiswaan pada IAIN Alauddin Ujungpandang (UIN Makassar), Koordinator Perguruan Tinggi Swasta (Wilayah VII Indonesia Bagian Timur), Pembantu Pimpinan Kepolisian Indonesia Timur dalam bidang pendidikan mental, dan lain-lain.

Quraish Shihab kembali ke Kairo pada tahun 1980 untuk melanjutkan pendidikannya. Pada Universitas yang sama di Al-Azhar, tahun 1982 ia berhasil meraih gelar Doktor dalam bidang ilmu-ilmu Alquran dengan judul disertasi Nazm Al-Durar li Al-Biqa'iy, Tahqiq wa Dirasah. Sekembalinya ke Indonesia, sejak 1984, Quraish Shihab ditugaskan di Fakultas Ushuluddin dan Fakultas Pascasarjana IAIN Syarif Hidayatullah (sekarang UIN Jakarta). Diluar kampus, ia menjabat berbagai jabatan. Antara lain: pada tahun 1984, sebagai Ketua Majelis Ulama Indonesia (MUI) Pusat, Anggota lajnah Pentashih Alquran Departemen Agama (sejak 1989), serta pernah menjadi menteri Agama Kabinet Pembangunan VII tahun 1998. ${ }^{3}$

\footnotetext{
${ }^{2}$ Quraish Shihab, Membumikan Alquran : Fungsi dan Peran Wahyu dalam Kehidupan Masyarakat (Bandung: Mizan, 2003)

${ }^{3}$ lbid.
} 
Ada beberapa karyanya yang sudah diterbitkan diantaranya adalah:

1. Tafsir Al-Manar, Keistimewaan dan Kelemahannya (Ujungpandang IAIN Alauddin, 1984)

2. Filsafat Hukum Islam (Jakarta: Departemen Agama, 1987).

3. Mahkota Tuntunan Ilahi (Tafsir Surah Al-Fatihah) (Jakarta, Untagma, 1988).

4. Membumikan Alqur'an: Fungsi dan Pran Wahyu dalam Kehidupan Masyarakat (Mizan, Mei 1992).

5. Tafsir Al-Amanah (Pustaka Kartini, November 1992).

6. Lentera Hati: Kisah dan Hikmah Kehidupan (MIzan, Pebruari 1994).

7. Tafsir Al-Quran Al-karim: Tafsir atas Surat-surat Pendek Brdasarkan Urutan Turunnya Wahyu (Pustaka Hidayah, September 1997).

8. Tafsir Al-Misbah : Pesan, Kesan dan Keserasian A-Qur'an (Lentera Hati, November 2000).

\section{Tafsir Al-Amanah}

\section{Asal Usul Tafsir Al-Amanah}

Pada dasarnya Tafsir al-Amanah adalah tafsir yang pernah dimuat dalam rubrik majalah dua mingguan di Jakarata yakni Majalah Amanah kemudian dibuat dalam bentuk karya buku tafsir yang dicetak oleh Pustaka Kartini pada bulan Agustus 1992. Tafsir al-Amanah hanya memuat dua pembahasan surah, yaitu surah al-'Alaq dan alMudatstsir. Tidak ada referensi yang menyebutkan tentang kenapa kata Al-Amanah menjadi nama bagi tafsirnya ini kecuali kemungkinan besar ada keterkaiatan historikal dengan majalah Amanah. Jadi, karya tafsir Al Amanah berasal dari tulisan yang sebelum dibukukan pernah dipublikasikan di Majalah. ${ }^{4}$

Selanjutnya, bila diperhatikan, Tafsir Al-Amanah sebenarnya merupakan cikal bakal tersusunnya Tafsir al-Qur'an al-Karim: Tafsir atas Surat-surat Pendek Berdasarkan Urutan Turunnya Wahyu. Yang merupakan karya tafsir Quraish Shihab yang terbit pada tahun 1997 oleh Pustaka Hidayah di Bandung. Terbukti bila membandingkan uraiannya, tampak bahwa uraian yang ada pada Tafsir Al-Amanah kelihatan sama dengan uraian yang ada pada Tafsir al-Qur'an al-Karim. Kendatipun pengolahan bahasa yang ada pada tafsir al-Qur'an al-Karim sudah kelihatan bagus dibanding Tafsir Al-Amanah. Quraish Shihab juga mengatakan bahwa sebagian uraian dalam karyanya yang berjudul Tafsir al-Qur'an al-Karim sudah disajikan pada tafsir amanah karya sebelumnya. ${ }^{5}$

${ }^{4}$ Islah Gusmian, Khazanah Tafsir Indonesia dari Hermeneutika hingga Ideologi ( Jakarta: Teraju, 2003), h.184.

${ }^{5}$ Quraish Shihab, Tafsir Al-Qur'an Al-Karim: Tafsir atas Surat-surat Pendek Berdasarkan Urutan Turunnya Wahyu ( Bandung: Pustaka Hidayah, 1997), h. vi 
Tafsir Al Amanah tampaknya belum mendapat simpatik atau pengaruh yang luar biasa pada masyarakat. Indikasinya dapat dilihat kalau karya Quraish ini tidak banyak orang membacanya. Oleh karena tidak dicetak secara berulang seperti pada karyakaryanya yang lain. Membumikan Alquran misalnya, karyanya ini tergolong "the best seller" terbukti dengan larisnya hingga terjual lebih dari 75.000 eksamplar. $^{6}$

\section{Latar belakang pemilihan surah}

Menurut Quraish Shihab, dalam bidang tafsir, ulama tafsir sepakat menyatakan bahwa cara yang terbaik dan terjamin kebenarannya dalam memahami Alquran adalah kembali kepada Alquran itu sendiri, serta kepada penjelasan Rasululah saw. sebagai mufassir pertama dan utama. Hal itulah yang menghendaki Quraish Shihab mengambil metode tersebut dalam menafsirkan ayat-ayat Alquran.

Metode tersebut dikenal sebagai metode bi al-Ma'tsur atau bi al-riwayah yang biasa dikenal dalam metodologi tafsir. Tafsir Al Amanah hanya membahas dua surah yaitu surah al-Alaq dan surah al-Mudatsir. Tampaknya kedua surah itu sengaja dipilih dengan dasar pertimbangan; (1) adanya kaidah-kaidah tafsir, baik yang ditarik dari Alquran maupun dari disiplin ilmu Alquran yang dikandung oleh surah yang dibahas, sehingga melalui kaidah tersebut, seseorang dapat menerapkannya pada ayat-ayat yang sama. (2) pembahasan yang dikandung oleh surah yang dipilih memiliki kaitan yang sangat erat dengan kehidupan beragama, bermasyarakat dan berbangsa. (3) perurutan dari segi turunnya ayat atau surah dapat memberikan gambaran tentang proses sejarah ajaran agama Islam. $^{7}$

Pada pertimbangan pertama, bisa dipahami bahwa ada keinginan yang serius pada Quraish untuk menunjukkan kepada setiap orang bahwa didalam Alquran ada banyak kaidah tafsir, sehingga dengan mengetahuinya, kaidah tersebut dapat dioperasionalkan pada ayat lain. Ini juga bisa dipahami bahwa dalam menguraikan ayatayat Alquran, Quraish selalu berusaha berangkat dari sebuah kaidah tafsir yang lahir dari Alquran itu sendiri. walaupun tidak dapat dinafikan keberadaan kaidah-kaidah lainnya yang mungkin saja muncul dari disiplin ilmu lain yang berkaitan dengan Alquran. Salah satu contoh kaidah yang dipergunakan adalah " suatu kata dalam susunan redaksi yang tidak disebutkan objeknya, maka objek yang dimaksudkannya itu bersifat umum, mencakup segala sesuatu yang dapat dijangkau oleh kata tersebut".

Penerapan kaidah ini, dapat dilihat misalnya pada saat kata iqra' ditafsirkan. Kata iqra' mencakup banyak arti, diantaranya adalah membaca, menelaah, menyampaikan dan sebagainya. Karena objeknya bersifat umum, maka objek kata tersebut mencakup segala yang dapat dijangkau, baik yang merupakan bacaan suci yang bersumber dari Tuhan, maupun yang bukan, atau yang menyangkut ayat-ayat yang

\footnotetext{
${ }^{6}$ Quraish Shihab, loc. Cit..

${ }^{7}$ Quraish Shihab, Tafsir Al Amanah, (Cet. I, t.tp: Pustaka Kartini, 1992), h. 8.
} 
tertulis maupun yang tidak tertulis, sehingga hal ini dapat mencakup telaah terhadap alam raya, masyarakat, dan manusia itu sendiri. ${ }^{8}$

Alasan pada pertimbangan kedua dapat dipahami bahwa kedua surah yang dipilih sebagai objek tafsirnya tersebut dipandang memiliki kandungan yang sangat dekat dengan kehidupan manusia, baik sebagai makhluk religius, maupun sebagai makhluk sosial. Pertimbangan ini, benar adanya, misalnya saja ketika dilihat penafsirannya tentang "hidayah".

'Kata "hidayah" berasal dari akar kata yang sama dengan "hidayat" yang menurut pengertian bahasa asalnya adalah "sesuatu yang mengandung arti petunjuk secara halus dan lemah lembut yang mengantar kepada yang diharapkan oleh pemberinya ...... naluri yang dianugrahkan Tuhan secara dini sejak kelahiran bayi merupakan potensi yang menjadi hidayah atau petunjuk untuk memenuhi kebutuhan-kebutuhan tertentu. Bayi yang baru lahir, pada saat merasa lapar dianugrahi Tuhan suatu petunjuk sehingga ia menangis dan sang ibu yang mendengar tangisnya menyodorkan ASI (air susu ibu) kemudian dengan naluri yang dianugrahkan Tuhan kepada si bayi, ia mengisap sehingga berhenti menangis.' 9

Contoh tersebut sangat dekat kaitannya dengan kehidupan sosial. Pengambilan contoh seperti itu mengindikasikan juga bahwa tafsir al-amanah tergolong tafsir sosial yang mengomentari banyak hal yang ada hubungannya dengan kehidupan di dalam masyarakat. Contoh lain dapat dilihat ketika uraian kata fitnah diangkat dan mengatakan bahwa fitnah yang dalam pengertian "membawa berita bohong " atau menisbahkan berita bohong kepada orang lain" adalah sesuatu pengertian yang sama sekali tidak ditemukan dalam Alquran. Lebih jauh Quraish Shihab mengatakan bahwa kelirulah orang yang menggunakan ayat al-fitnatu asyaddu min al-qatli dalam konteks pemberitaan bohong. Kata fitnah dalam Alquran mengandung arti, membakar, menyiksa, cobaan, kesesatan atau penyimpangan. ${ }^{10}$

\section{Sistematika Penyajian tafsir}

Sistematika penyajian tafsir yang dimaksud adalah rangkaian yang dipakai dalam penyajian tafsir. Sebuah karya tafsir, secara teknis bisa saja disajikan dalam sistematika penyajian yang beragam. Tafsir Al-Amanah misalnya, dalam sisi sistematika penyajiannya dapat dikelompokkan menjadi dua bagian pokok: (1) sistematika penyajian runtut, yakni model sistematika penyajian tafsir yang rangkaian penyajiannya mengacu pada urutan surah yang ada dalam mushaf, atau mengacu pada

\footnotetext{
${ }^{8}$ Ibid., h. 12

${ }^{9}$ Ibid., h. 56

${ }^{10}$ lbid., h. 168.
} 
urutan turunnya wahyu, biasa disebut dengan istilah tahliliy dan (2) sistematika penyajian tematik, yakni suatu bentuk rangkaian penulisan karya tafsir yang struktur paparannya diacukan pada tema tertentu atau pada ayat, surah, dan juz tertentu. Dan ternyata tafsir ini mengkhususkan pada dua surah saja.

Tafsir Al-Amanah digolongkan masuk pada kelompok tafsir yang sisi penyajiannya tematik, karena dipilihnya surah tertentu. Tematik disini bukan tematik seperti yang dibangun oleh al-Farmawi dan dipopulerkan oleh Quraish Shihab sebagai metode tafsir, akan tetapi tematik dalam pengertian sebagai teknik penulisan tafsir. Dalam model penyajian tematik ini, Quraish biasanya menjelaskan lebih awal kata kunci pada setiap ayat yang nantinya saling berkorelasi dengan ayat lainnya. Misalnya ketika menguraikan makna khalaqa dan al-Insan pada surah al-'Alaq. Dalam uraiannya, Quraish tidak hanya fokus pada kata khlaqa, akan tetapi lebih jauh ia membandingkannya pula dengan kata ja'ala. Bahkan, sering memaparkan ayat-ayat yang semakna dengan kata kunci yang ia jelaskan. Dari sinilah kelihatan sekali penyajian yang sifatnya tematik.

\section{Bentuk penyajian dan nuansa Tafsir}

Bentuk penyajian tafsir yang dimaksud adalah suatu bentuk uraian dalam penyajian tafsir yang ditempuh mufassir dalam menafsirkan Alquran. Tafsir Al-Amanah memiliki bentuk penyajian yang rinci bukan bersifat global. Uraian penafsiran secara detail, mendalam, dan komprehensif.

Terma-terma kunci di setiap ayat dianalisis untuk menemukan makna yang tepat dan sesuai dalam suatu konteks ayat. Pengungkapan asbab al-nuzul tidak luput diangkat sebagai bagian dari metode penafsirannya. Bahkan analisis linguistik dan sosiohistoris sangat kental dirasakan dalam tafsir ini. Rujuklah misalnya ketika kata "al-jannah" pada ayat 40 surah al-Muddatsir diuraikan dengan pendekatan bahasa.



“ ... "jannah" yang biasa diterjemahkan dengan surga terambil dari kata "janana" yang berarti tertutup. Dari akar kata ini terbentuk berbagai kosakata seperti "janinun" (janin) yaitu anak yang masih dalam kandungan. Ia dinamai demikian, karena ia masih tertutup oleh perut ibu. "Jin" (makhluk halus) dinamai demikian karena hakikatnya tidak diketahui atau karena wujudnya tidak terlihat (tertutup) bagi pandangan manusia. Seorang yang gila (tertutup akalnya) dinamai "majenun". Kebun/taman yang dipenuhi oleh tumbuh-tumbuhan sehingga menutupi pandangan manusia dinamai "jannah"."11

Demikian salah satu contoh yang dapat dirasakan analisis linguistiknya.

${ }^{11}$ /bid., h. 202 
Sebenarnya karya Tafsir Al Amanah termasuk sangat kaya dengan nuansa kebahasaan. Karena pada umumnya dalam proses interpretasi selalu berangkat dari analisis kebahasaan. Biasanya ditemukan uraian yang sangat panjang tentang asal-usul kata dalam sebuah ayat, perubahan-perubahannya, keragaman maknanya, serta bangunan semantiknya dengan kata-kata yang lain.

Model uraian semacam ini, dilakukan Quraish Shihab dengan konsisten setiap ayat pada surah-surah yang dikajinya di buku tafsir ini. Ia sangat memperhatikan arti kosa kata atau ungkapan Alquran dengan merujuk kepada pandangan para pakar bahasa, memperhatikan bagaimana kosa kata itu digunakan oleh Alquran, dan memahami arti ayat atas dasar digunakannya kata tersebut oleh Alquran.

Langkah ini memang tergolong penting karena mengingat bahwa Alquran tidak jarang mengubah pengertian semantic dari satu kata yang digunakan oleh masyarakat Arab ditemuinya, kemudian member muatan makna yang berbeda pada kata tersebut.

Dalam konteks mengetahui makna-makna kosakata disetiap ayat, yang ditempuh oleh Quraish Shihab, memang cukup baik dan sangat dirasakan nunsa kebahasaannya. Namun, penekanan yang cukup kuat pada analisis bahasa bisa melahirkan resiko kebosanan khususnya bagi pembaca yang ingin menangkap dan memahami pesanpesan dasar Alquran.

Gambaran terhadap penyajian yang bernuansa bahasa atau linguistik yang sangat kental sepertinya memang sudah menjadi metode tersendiri bagi Quraish Shihab. Karena itu, ia seperti menjadikan sebagai dasar dalam membangun suatu konsepsi yang ditarik dari suatu ayat yang dikaji, walaupun memang biasanya model semacam ini digunakan dalam sistematika penyajan tematik. Tafsir tematik dalam sistematika penyajiannya selalu menggunakan analisis atas makna kata serta medan semantiknya yang berkaitan dengan tema pokok bilamana ingin menemukan suatu konstruksi konseptual yang komprehensif.

Dalam penyajiannya, juga selalu menyertakan ayat-ayat yang ada kaitannya dengan yang diuraikan bahkan tidak jarang juga menampilkan hadis sebagai pendukung argumentasinya, termasuk qaul sahabat dan tabi'in. Model seperti ini biasa disebut model tafsir bi al-ma'tsur atau bi al-riwayah. Penyajian dengan model bi alma'tsur sebenarnya sudah menjadi alur penafsiran yang selalu dibangun oleh Quraish Shihab. Dan hal ini selalu diungkap di beberapa pendahuluan karya tafsirnya. ${ }^{12}$

Ke-ma'tsuran tafsirnya ini, tidak juga berarti menafikan sumber-sumber lain atau literatur yang dapat menjadi pelengkap uraiannya. Bahkan kadang-kadang mengangkat nama tokoh atau ilmuwan yang ada keterkaitannya dengan penjelasan

${ }^{12}$ Tafsir bi al-matsur adalah tafsir yang dalam menafsirkan Alquran lebih banyak merujuk kepada riwayat dalam hal ini hadis-hadis nabawi dan pendapat para sahabat bahkan tabi'in dan atau tabi' tabi' in ketimbang penafsirkan berdasarkan penalaran. Lihat Muhamad Ali al-Shabuni, al-Tibyan fi 'Ulum al-Qur'an (Bairut: Dar al-Fikr, t.th.), h. 75. 
tafsirnya. Tafsir Al Amanah juga tergolong tafsir bi al-dirayah, karena dalam uraian penafsirannya banyak bersandar kepada kosakata-kosakata dalam ayat-ayat Alquran berdasarkan kaidah-kaidah bahasa Arab dan pendekatan-pendekatan keilmuan lainnya.

\section{E. Kesimpulan}

Berdasarkan uraian dan rumusan masalah sebelumnya, maka dapat ditarik kesimpulan:

1. Tafsir Al Amanah merupakan satu diantara karya-karya tafsir Quraish Shihab yang pernah terbit. Awalnya merupakan tulisan-tulisan yang pernah dimuat di majalah Amanah. Tafsir ini hanya memuat dua bahasan surat, yaitu surat al'Alaq dan al-Mudatstsir. Dalam uraiannya terhadap ayat yang dibahas, dapat digolongkan sebagai uraian tahliliy karena runtut uraiannya dari ayat ke ayat. Di samping itu, tafsir ini juga bisa disebut penyajiannya sebagai sajian tafsir tematik, namun bukan tematik yang seperti dikonstruksi oleh Al-Farmawi. Dikatakan tematik karena pilihan surat-suratnya yang spesifik kepada dua surah saja.

2. Dari segi metodologi, Tafsir Al Amanah termasuk tafsir yang beraliran tafsir $b i$ al-riwayah dan bi al-dirayah. Gabungan dari kedua aliran atau warna tafsir yang selama ini dikenal. Tafsir Al-Amanah memiliki sajian tafsir yang rinci, mendetail, mendalam, dan komprehensif. Terma-terma kunci di setiap ayat dianalisis untuk menemukan makna yang tepat dan sesuai dalam suatu konteks ayat. Pengungkapan asbab al-nuzul tidak luput diangkat sebagai bagian dari metode penafsirannya selama ayat itu memiliki asbab al-nuzul. Bahkan analisis linguistik dan sosiohistoris sangat kental dirasakan dalam tafsir ini.

\section{DAFTAR PUSTAKA}

Departemen Agama RI. Al-Qur'an dan Terjemahnya. Semarang: Asy-Syifa', 2000

Federsipel, Howard M. Kajian Alquran Di Indonesia: Dari Mahmud Yunus hingga Quraish Shihab. Bandung: Mizan, 1996

Gusmian, Islah. Khazanah Tafsir Indonesia dari Hermeneutika hingga Ideologi. Jakarta: Teraju, 2003.

Al-Shabuni, Muhamad Ali. al-Tibyan fi 'Ulum al-Qur'an. Bairut: Dar al-Fikr, t.th.

Shihab, Quraish. Tafsir Al-Manar, Keistimewaan dan Kelemahannya (Ujungpandang IAIN Alauddin, 1984) 
--------,. Mahkota Tuntunan Ilahi (Tafsir Surah Al-Fatihah) (Jakarta, Untagma, 1988).

--------, Tafsir Al Amanah. Cet. I, t.tp: Pustaka Kartini, 1992.

-,Lentera Hati: Kisah dan Hikmah Kehidupan. Mizan: Bandung, 1994.

-Tafsir Al-Qur'an Al-Karim: Tafsir atas Surat-surat Pendek Berdasarkan Urutan Turunnya Wahyu. Bandung: Pustaka Hidayah, 1997.

-------,Tafsir Al-Misbah : Pesan, Kesan dan Keserasian A-Qur'an. Lentera Hati, November, 2000

--------, Membumikan Alquran : Fungsi dan Peran Wahyu dalam Kehidupan Masyarakat. Bandung: Mizan, 2003.

Al-Suyuthy, Abd Rahman Jalal al-Din. al-Dur al-Mansur fi al tafsir al-Ma'sur, Jilid I, Bairut: Dar al-Fikr, 1983.

al-Thabary, Muhammad bin Jarir. Jami' al-Bayan fi Ta'wil al-Qur;an, t.tp.: Mu'assasah al-risalah, 2000. 